\title{
KORELASI DURASI PENGGUNAAN KONTRASEPSI ORAL DAN STADIUM KANKER SERVIKS DI RSUD ARIFIN ACHMAD PROVINSI RIAU
}

\section{THE CORRELATION OF ORAL CONTRACEPTIVES USING DURATION AND STAGE OF CERVICAL CANCER AT ARIFIN ACHMAD HOSPITAL RIAU}

\author{
Feriandri Utomo $^{1 *}$, Ahmad Afandi ${ }^{2}$, Syamsul Bahri $^{3}$ \\ ${ }^{I}$ Departemen Ilmu Kedokteran Dasar, Fakultas Kedokteran dan Ilmu Kesehatan Universitas \\ Abdurrab, Jl Riau Ujung No. 73, Pekanbaru, 28292, Indonesia \\ ${ }^{2}$ Prodi Pendidikan Dokter, Fakultas Kedokteran dan Ilmu Kesehatan Universitas Abdurrab, Jl Riau \\ Ujung No. 73, Pekanbaru, 28292, Indonesia \\ ${ }^{3}$ Departemen Ilmu Kedokteran Klinik, Fakultas Kedokteran dan Ilmu Kesehatan, Universitas \\ Abdurrab, Jl Riau Ujung No. 73, Pekanbaru, 28292, Indonesia \\ *Surel: feriandri.utomo@univrab.ac.id
}

\begin{abstract}
Abstrak
Insidensi kanker serviks terus meningkat, termasuk di RSUD Arifin Achmad Provinsi Riau, di mana terjadi hampir 8 kali peningkatan insidensi kanker serviks pada tahun 2017 dibandingkan pada tahun 2016. Penggunaan kontrasepsi oral yang menjadi salah satu faktor risiko kanker serviks, juga mengalami peningkatan drastis di Provinsi Riau. Durasi penggunaan kontrasepsi oral terbukti berhubungan signifikan terhadap peningkatan risiko Cervical Intraepithelial Neoplasia grade 3 (CIN3). Penelitian ini bertujuan untuk menganalisis hubungan antara durasi penggunaan kontrasepsi oral dengan stadium kanker serviks. Penelitian ini merupakan penelitian analitik observasional, dengan rancangan cross sectional. Pengambilan sampel dilakukan dengan teknik total sampling pada data rekam medis pasien selama tahun 2017 di RSUD Arifin Achmad Provinsi Riau dan diuji secara statistik menggunakan uji korelasi Spearman Rank. Penelitian ini menemukan terdapat korelasi kuat yang signifikan antara durasi penggunaan kontrasepsi oral dengan stadium kanker serviks ( $p$-value < $0,05$ dan $r=0,74)$. Selain itu, durasi penggunaan kontrasepsi oral berpengaruh terhadap peningkatan stadium kanker serviks sebesar 54,7\% $\left(\mathrm{r}^{2}=0,547\right)$. Dari penelitian ini dapat disimpulkan bahwa durasi penggunaan konstrasepsi oral sangat berhubungan dengan peningkatan stadium kanker serviks.
\end{abstract}

Kata kunci: Kanker, Kontrasepsi, Serviks, Stadium 


\begin{abstract}
The incidence of cervical cancer increases, including in Arifin Achmad Regional Hospital in Riau, there has been an almost 8 times increase in the number of cervical cancer in 2017 compared to 2016. The use of oral contraceptives, which is one of the risk factors for cervical cancer, has been also increasing dramatically in Riau Province. The duration of oral contraceptive use has been shown to be significantly related to an increased risk of grade 3 cervical intraepithelial neoplasia (CIN3). This study aims to analyze the relationship between duration of oral contraceptive use and cervical cancer stage. This research was an observational analytic study, with cross sectional design. Sampling was done by total sampling technique on medical record during 2017 at Arifin Achmad Regional Hospital in Riau and statistically tested using the Spearman Rank test. This study found a significant strong correlation between the duration of oral contraceptive use and the stage of cervical cancer ( $p<0.05$ and $r=0.74$ ). The duration of use of oral contraceptives affected the increase in stage of cervical cancer by $54.7 \%\left(r^{2}=0.547\right)$. This study conclude that duration of use of oral constructs is strongly associated with an increase in the stage of cervical cancer.
\end{abstract}

Keywords: Cancer, Cervix, Cotraceptives, Stage

\section{Pendahuluan}

Insidensi kanker serviks di dunia pada tahun 2012 mencapai 528.000 kasus baru dengan angka kematian 266.000. (1) Di Indonesia sendiri dalam kurun waktu 2008 sampai 2012 terjadi peningkatan kasus baru kanker serviks. Data insidensi penyakit kanker serviks di Indonesia tahun 2008, yaitu 15.000 kasus baru, untuk tahun 2012 terjadi peningkatan estimasi kasus baru sebesar 20.928. (2,3)

Berdasarkan survei pendahuluan di RSUD Arifin Achmad Provinsi Riau menggunakan rekam medis, terjadi peningkatan kunjungan pasien dan angka kematian dengan penyakit kanker serviks di mana pada tahun 2016 ditemukan 54 pasien dengan angka kematian 8 orang. Pada tahun berikutnya terjadi peningkatan signifikan di mana tahun 2017 terdapat 425 pasien dengan angka kematian 17 orang, dan laporan data terakhir rekam medis tahun 2018 pada semester pertama dari bulan Januari-Juli jumlah kunjungan pasien dengan kanker serviks sebesar 360 dengan angka kematian 17 orang.

Faktor risiko yang dapat meningkatkan peluang terjadinya kanker serviks antara lain usia pertama kali berhubungan seksual, usia pertama kali hamil, riwayat abortus, penggunaan pil kontrasepsi dalam jangka waktu yang lama yaitu lebih dari 5 tahun. (4) Selain itu, Rouora et al menyatakan faktor hormonal berupa penggunaan kontrasepsi oral berkaitan dengan kanker serviks. (5)

Data terakhir penggunaan kontrasepsi pil (oral) dalam rentang 8 bulan terakhir, khususnya di Provinsi Riau, pada bulan Januari 2018 terdapat sejumlah 204.182 pengguna dan pada bulan Agustus 2018 meningkat sebanyak 717.821. (6) Penggunaan pil (oral) sebagai alat kontrasepsi terbanyak 
kedua yang diminati dan terjadi peningkatan penggunaannya di Provinsi Riau. (6)

Hubungan penggunaan kontrasepsi oral sebagai faktor risiko pada kanker serviks terjadi karena hormon steroid diperkirakan meningkatkan ekspresi early 6 (E6) dan early 7 (E7) Human Papilloma Virus (HPV) 16 onkogen yang pada gilirannya menurunkan produk gen protein 53 (p53) dan meningkatkan kemampuan virus untuk mengubah sel dan menginduksi karsinogenesis. (7) Protein 53 (p53) sebagai supressor tumor diduga paling banyak berperan, fungsi p53 sebagai negative control cell cycle dan guardion of genom (penjaga genom) mengalami degradasi karena membentuk kompleks E6-p53 atau mutasi p53. Apabila terjadi degradasi yang luar biasa pada p53 maka akan terjadi karsinogenesis tanpa terkendali. (7) Estrogen dan progesteron yang terdapat pada kontrasepsi oral mampu mempengaruhi sel-sel leher rahim melalui transkripsi mRNA HPV. Selain itu, steroid seks dapat meningkatkan ekspresi gen HPV E6 dan E7, yang pada akhirnya dapat menyebabkan kegagalan apoptosis dan mempromosikan karsinogenesis. (8) Durasi penggunaan kontrasepsi pil (oral) berhubungan secara signifikan terhadap peningkatan risiko Cervical Intraepithelial Neoplasia grade 3 (CIN3). (5) Oleh karena itu, penelitian ini akan mengungkap dugaan terdapat hubungan durasi penggunaan kontrasepsi oral dengan stadium kanker serviks di RSUD Arifin Achmad Provinsi Riau.

\section{Metode}

Penelitian ini merupakan penelitian analitik observasional, dengan rancangan cross sectional. Penelitian ini dilakukan di RSUD Arifin Achmad Provinsi Riau pada bulan Mei tahun 2019. Variabel independen dalam penelitian ini adalah durasi penggunaan kontrasepsi oral (tahun), sedangkan variabel dependennya adalah stadium (stage) kanker serviks. Pada penelitian ini, pembagian stadium kanker serviks disesuaikan dengan klasifikasi The International Federation of Gynecology and Obstetrics (FIGO) yaitu (7):

- Stadium 0 : Karsinoma insitu (sama dengan FIGO)

- Stadium 1 : Karsinoma hanya terbatas pada serviks (FIGO: stadium 1, 1A, 1A1 1A2, 1B, 1B1, 1B2)

- Stadium 2 : Invasi tumor keluar dari uterus tetapi tidak sampai ke dinding panggul atau mencapai $1 / 3$ bawah vagina (FIGO: stadium 2, 2A, 2B)

- Stadium 3 : Tumor meluas ke dinding panggul atau mencapai $1 / 3$ bawah vagina dan atau menimbulkan 
hidronefrosis atau afungsi ginjal

(FIGO: stadium 3, 3A dan 3B)

- Stadium 4: Tumor menginvasi mukosa kandung kemih atau rektum dan atau meluas keluar panggul kecil (FIGO: stadium 4A dan 4B).

Pengambilan sampel dilakukan dengan cara total sampling pada data rekam medis pasien kanker serviks selama tahun 2017 di RSUD Arifin Achmad Provinsi Riau dan diuji secara statistik menggunakan uji korelasi Spearman Rank.

\section{Hasil}

Penelitian ini dilakukan pada 107 sampel pasien kanker serviks dengan karakterisktik paling banyak menggunakan kontrasepsi oral kurang dari 5 tahun sebanyak 61 orang pasien. Selain itu, ditemukan pula stadium kanker serviks yang terbanyak adalah pada stadium 2 sebesar 22 pasien (Tabel 1).

Tabel 1. Durasi Penggunaan Kontrasepsi Oral dan Stadium Kanker (CA) Serviks

\begin{tabular}{lcccccc}
\hline \multirow{2}{*}{ DURASI I } & \multicolumn{4}{c}{ STADIUM CA } & \multirow{2}{*}{ JUMLAH } \\
\cline { 2 - 5 } & $\mathbf{0}$ & $\mathbf{1}$ & $\mathbf{2}$ & $\mathbf{3}$ & $\mathbf{4}$ & \\
\hline$<5$ tahun & 10 & 14 & 22 & 11 & 4 & 61 \\
$\geq 5$ tahun & 1 & 1 & 6 & 18 & 20 & 46 \\
JUMLAH & 11 & 15 & 28 & 29 & 24 & 107 \\
\hline
\end{tabular}

Hasil penelitian ini menunjukkan bahwa terdapat hubungan durasi penggunaan kontrasepsi oral dengan stadium kanker serviks secara signifikan ( $p$-value $<0,05)$. Selain itu, dengan analisis statistik korelasi Spearman Rank, ditemukan pula kekuatan hubungan atau korelasi yang kuat dengan arah positif $(r=0,74)$ yang artinya semakin lama penggunaan kontrasepsi oral maka akan semakin meningkat stadium kanker serviks. Dari analisis statistik penelitian ini juga didapatkan koefisien determinasi $\left(r^{2}\right) \%$ yaitu 0,547 yang bermakna bahwa faktor durasi penggunaan kontrasepsi oral berpengaruh terhadap peningkatan stadium kanker serviks sebesar $54,7 \%$. Faktor-faktor lainnya yang berpengaruh terhadap peningkatan stadium kanker serviks adalah sebesar $45,3 \%$.

\section{Pembahasan}

Penelitian ini menemukan hubungan kuat yang signifikan antara durasi penggunaan kontrasepsi oral dengan stadium kanker serviks ( $p$-value $<0,05$ dan $\mathrm{r}=0,740$ ). Penelitian Vaisy et al juga memiliki hasil yang sejalan dengan penelitian ini yaitu terdapat hubungan antara riwayat penggunaan kontrasepsi oral 2,4 kali lebih berisiko penggunaan lebih dari 5 tahun terhadap perkembangan kanker serviks. (9) Faktor utama dalam perkembangan kanker serviks yaitu HPV, akan tetapi kontrasepsi oral yang berisi hormon estrogen dapat meningkatkan pertumbuhan neoplastik. (9) Wanita dengan 
kadar reseptor estrogen yang lebih tinggi secara signifikan memungkinkan terjadinya pengikatan transkripsi pada DNA HPV yang memicu terjadinya karsinogenesis.

Penelitian Zidi et al juga menemukan penggunaan kontrasepsi oral 1,86 kali lebih berisiko terhadap kejadian kanker serviks stadium lanjut atau III dan IV dari pada yang tidak menggunakan kontrasepsi oral. (10)

Hasil penelitian ini sejalan pula dengan hasil penelitian $\mathrm{Oh}$ et al yang menemukan setiap penggunaan kontrasepsi oral dan penggunaan jangka panjang (> 20 bulan) dikaitkan dengan peningkatan CIN 2 dan CIN 3. (11) Kondisi tersebut terjadi karena hormon estrogen dapat meningkatkan transkripsi onkogen HPV E6 yang mengarah pada degradasi produk gen p53 dan kegagalan pada siklus sel G1/S, sehingga menginduksi karsinogenesis. (11) Peningkatan kanker serviks invasive juga ditemukan pada penggunaan kontrasepsi oral dan terjadi penurunan setelah penghentian kontrasepsi oral. (11)

Penelitian yang dilakukan Berraho et al juga mendapatkan hasil yang sejalan dengan penelitian ini yaitu adanya peran kofaktor berupa penggunaan kontrasepsi oral selama lebih dari 6 tahun terhadap terjadinya kanker serviks yang invasive. (12) Selain itu, Luhn et al menyatakan yaitu terdapat hubungan antara penggunaan kontrasepsi oral dengan perkembangan terhadap CIN 3 dan peningkatan risikonya terjadi ketika penggunaan kontrasepsi oral lebih dari 10 tahun. (13) Estrogen yang terdapat pada kontrasepsi oral berperan terhadap perkembangan kanker serviks dan menjadi prekursor langsung terhadap terjadinya CIN 3.

Hasil penelitian ini sejalan dengan penelitian $\mathrm{Xu}$ et al yang mendapatkan adanya hubungan antara penggunaan kontrasepsi hormonal terhadap peningkatan perkembangan CIN 3 dan risiko terjadinya perkembangan kanker serviks seiring dengan meningkatnya durasi penggunaan kontrasepsi hormonal lebih dari 10 tahun. (14) Penggunaan kontrasepsi hormonal secara persisten mempromosikan infeksi HPV onkogenik yang dapat menyebabkan perkembangan kanker serviks. (14) Selain itu, beberapa penelitian sebelumnya juga menemukan mekanisme sinergis antara onkogen dari HPV 16 dan paparan estrogen kronis yang dapat menyebabkan karsinogenesis sel skuamosa. (14)

Penelitian ini juga sejalan dengan penelitian yang dilakukan Khatun et al yang menemukan penggunaan kontrasepsi oral dengan durasi 5 tahun berhubungan dengan terjadinya cervical carcinoma invasive. (15) Inisiasi lesi prakanker serviks disebabkan oleh Human Papiloma Virus (HPV) dan 
kontrasepsi oral menjadi kofaktor HPV, serta reseptor hormon estrogen dan progesteron yang penting untuk perkembangan kanker serviks. (15) Pernyataan ini didukung dengan penelitian yang dilakukan oleh Samir et al yang mendapatkan adanya peningkatan kadar progesteron pada high grade squamous intraephitelial lesion. (16)

Penelitian ini juga sejalan dengan penelitian Rouora et al yang menemukan adanya hubungan yang signifikan antara lama penggunaan kontrasepsi pil oral dengan CIN3. (5) Mekanisme yang diduga dapat menjelaskan adanya hubungan antara penggunaan kontrasepsi oral dan perkembangan kanker serviks adalah estrogen dan progesteron yang terdapat pada kontrasepsi oral dapat meningkatkan ekspresi onkogen HPV 16 E6 dan E7 yang merangsang degradasi gen penekan tumor p53 yang menyebabkan karsinogenesis.

\section{Kesimpulan}

Dari hasil penelitian ini disimpulkan bahwa durasi penggunaan kontrasepsi oral berhubungan kuat secara signifikan dengan stadium kanker serviks di RSUD Arifin Achmad Provinsi Riau. Selain itu, durasi penggunaan kontrasepsi oral juga menjadi faktor yang berperan besar (> 50\%) sebagai penyebab terjadinya peningkatan stadium kanker serviks. Oleh karena itu, dibutuhkan penelitian yang lebih mendalam di masa depan untuk mengungkap mekanisme kontrasepsi oral atau hormon dapat meningkatkan stadium kanker serviks. Mekanisme tersebut penting untuk memastikan keamanan penggunaan kontrasepsi oral dan menjadi referensi awal untuk menemukan kontrasepsi yang tak berpengaruh pada karsinogenesis, sehingga lebih aman bagi masyarakat pengguna kontrasepsi.

\section{Referensi}

1. Ferlay J., Soerjomataram I., Dikshit R., Eser S., Mathers C., Rebelo M., Parkin D.M., Forman D., et al. 'Cancer incidence and mortality - Major patterns in GLOBOCAN 2012, worldwide and Georgia', Bulletin of the Georgian National Academy of Sciences. 2015; 9(1), pp. 168-173. doi: 10.1002/ijc.29210.

2. Domingo E.J., Noviani R., Noor M.R.Md., Ngelangel C.A., Limpaphayom K.K., Thuan T.V., Louie K.S., et al. 'Epidemiology and Prevention of Cervical Cancer in Indonesia, Malaysia, the Philippines, Thailand and Vietnam', Vaccine. 2008; 26(SUPPL. 12). doi: 10.1016/j.vaccine.2008.05.039.

3. Momenimovahed, Z. and Salehiniya, H. Incidence, mortality and risk factors of cervical cancer in the world, Biomedical Research and Therapy. 2017; 4(12), p. 
1795. doi: 10.15419/bmrat.v4i12.386.

4. Wulandari, V. 'Hubungan Faktor Risiko Penggunaan Kontrasepsi Oral dan Aktivitas Seksual Dengan Kejadian Kanker Serviks', Jurnal Berkala Epidemiologi. 2016; 4(3), pp. 408-419. doi: 10.20473/jbe.v4i3.

5. Rouora E., Travier N., Waterboer T., Sanjoese S.D., Bosch F.X., Pawlita M., Pala V., et al. 'The Influence of Hormonal Factors on the Risk of Developing Cervical Cancer and Pre-Cancer', Indian Journal of Animal Sciences. 2016; 80(4 SUPPL. 1), pp. 85-97. doi: 10.1371/journal.pone.0147029.

6. BKKBN. PESERTA KB AKTIF MENURUT METODE KONTRASEPSI BULAN:Agustus 2018; 2018a. Available from:

http://aplikasi.bkkbn.go.id/sr/DALLAP/La poran2013/Bulanan/Dalap2013Tabel15.as px (Diakses 18 September 2018).

7. Kumar, V., K.Abbas, A. and C.Aster, J. BUKU AJAR PATOLOGI Robbins. 9th edn. Edited by S. Tharmapalan. Singapore: Elsevier (Singapore); 2015.

8. Volpato L.K., Siqueira I.R., Nunes R.D., Piovezan A.P. 'Association between hormonal contraception and injuries induced by human papillomavirus in the Uterine Cervix', Revista Brasileira de Ginecologia e Obstetricia. 2018; 40(4), pp. 196-202. doi: 10.1055/s-00381642603.

9. Vaisy, A., Lotfinejad, S. and Zhian, F. 'Risk of Cancer with Combined Oral Contraceptive Use among Iranian Women', 15, pp. 5517-5522; 2014.

10. Zidi S., Sahli M., Mezlini A., Loueslati B.Y. 'Association of Combined Tobacco Smoking, Hormonal Contraceptive use and Status Matrimonial with Cervical Cancer Evolution in Tunisian Women'. Pathology \& Oncology Research; 2018.

11. Oh, H. Y., Kim M. K., Seo, S. S., Lee J. 'Association of Combined Tobacco Smoking and Oral Contraceptive Use With Cervical Intraepithelial Neoplasia 2 or 3 in Korean Women'. 2016; 26(1), pp. 22-29. doi: 10.2188/jea.JE20150047.

12. Berraho, M., Riffi A. A., El-Mzibir M., Bezad R., Benjaafar N., Benideer A., et al 'HPV and cofactors for invasive cervical cancer in Morocco: a multicentre casecontrol study'. BMC Cancer. 2017; pp. 19. doi: 10.1186/s12885-017-3425-z.

13. Luhn, P., Walker J., Schiffman M., Zuna R. E., Dunn S. T., Gold M. A., Smith K. et al. 'The role of co-factors in the progression from human papillomavirus infection to cervical cancer', Gynecologic Oncology. Elsevier B.V. 2013; 128(2), pp. 265-270. doi: 10.1016/j.ygyno.2012.11.003. 
14. Xu H., Egger S., Valentzis L. S., O'Connel D. L., Banks E., Brown J. D., Canfell K. 'Hormonal contraceptive use and smoking as risk factors for high-grade cervical intraepithelial neoplasia in unvaccinated women aged $30-44$ years : A case-control study in New South Wales, Australia', Cancer Epidemiology. Elsevier. 2018; 55(March), pp. 162-169. doi: 10.1016/j.canep.2018.05.013.

15. Khatun, S. F., Khatun S., Hossain A. K. M. F., Nahar K. 'Prolonged use of oral contraceptive pill, a co-factor for the development of cervical cancer', $A$ Journal of Bangabandhu Sheikh Mujib Medical University, Dhaka, Bangladesh. 2018; doi: 10.3329/bsmmuj.v11i3.37279.

16. Samir, R., Tot T., Asplund A., Pekar G., Hellberg D. 'Increased Serum Progesterone and Estradiol Correlate to Increased COX-2 Tissue Expression in Cervical Intraepithelial Neoplasia'. 2010; 1222, pp. 1217-1222. 